Стаття присвячена актуальному питанню визначення теплотехнічних характеристик вогнегасного порошку для теплоізоляиіі осередку пожежі стружкових матеріалів на основі сплавів магнію з метою запобігання розвитку та поширення пожежі та ефективного ї̈ гасіння. Для вирімення даної задачі проведені лабораторні та полігонні експериментальні дослідження теплоізолювальної здатності вогнегасного пороику комбінованої дії. У результаті одержані дані щодо температури у осереджу пожежі стружкових матеріалах на основі магнієвих сплавів та за його межами при їх гасінні вогнегасним порошком комбінованої дії. При цьому температура необігрівної сторони шару вогнегасного порошку не перевищуе $170{ }^{\circ} \mathrm{C}$ при середній температурі осередку пожежі $740{ }^{\circ} \mathrm{C}$, що показуе високу теплоізоляційну здатність пороику $i$, як наслідок, його високу вогнегасну ефективність при гасінні пожеж стружкових матеріалів на основі сплавів магнію. Отримані температурні дані були використані для визначення теплофізичних параметрів шару вогнегасного порошку з використанням створеної математичної моделі процесу теплопередачі у шарі порошку при тепловій ізоляції осередку пожежі. Для створення математичної моделі процесу теплопередаиі були сформульовані основні положення при послідовному розгляді декількох експериментальних ситуацій. Перша експериментальна ситуачіл відповідає умовам стаціонарного теплового процесу, а інші експериментальні ситуаціі відповідають умовам нестаціонарного теплового процесу. Створення даних експериментальних ситуацій відбувалося за допомогою зміни товщини шару вогнегасного порошку при різних параметрах його подавания в осередок пожежі. Розроблена математична модель процесу базується на використанні диференціального рівняння теплопередачі при його апроксимації за методом кінцевих різниць. При цьому вважається, що умови тепловіддачі на границі між необігрівною стороною ізолюючого шару вогнегасного порошку та оточуючим середовищем у кожній експериментальній ситуації є однаковими.

3 використанням створеної моделі був визначений коефіцієнт тепловіддачі між необігрівною стороною ізолюючого шару вогнегасного порошку та оточуючим середовищем, який склав $395.7 \mathrm{Bm} /\left(\mathrm{M}^{2}{ }^{\circ} \mathrm{C}\right)$. Досліджена залежність ефективного коефіцієнта теплопровідності від товщини ізолюючого цару. Показано, що дана залежність може бути апроксимована лінійною залежністю $\lambda(\delta)=-0.016+93.907 \cdot \delta(\delta-$ товщина шару вогнегасного порошку в метрах).

Провівии необхідні розрахунки, було отримане значення необхідної товщини шару вогнегасного пороику $\delta=45.2 \mathrm{m.M}$

Ключові слова: вогнегасний порошок, горіння металів, сплави магнію, ізолюючий шар, інтенсивність гасіння
UDC 614.8

DOI: $10.15587 / 1729-4061.2020 .201748$

\section{THERMOTECHNICAL PROPERTIES OF THE FIRE- EXTINGUISHING POWDER FOR EXTINGUISHING MATERIALS BASED ON MAGNESIUM ALLOY CHIPS}

\author{
B. Gusar \\ Adjunct* \\ E-mail: bogdan.gusar.94@gmail.com \\ V. Koval y s h y n
}

Doctor of Technical Sciences, Professor, Head of Department*

E-mail: kovalyshyn.v@gmail.com

S. Pozdie i e v

Doctor of Technical Sciences, Professor, Head Researcher** E-mail: svp_chipbbk@ukr.net

Vol. Kovalyshyn

PhD, Deputy Head

Main Control Service Emergencies Ukraine in Lviv

Pidvalna str., 6, Lviv, Ukraine, 79008

E-mail:vkovalushun1106@gmail.com

0. Z e m li a n s k y i

$\mathrm{PhD}$, Associate Professor

Department of Automatic Safety Systems and Electrical Installations**

E-mail: omzem1@gmail.com

K. My hale n k o

$\mathrm{PhD}$, Associate Professor, Deputy Head Department of Automatic Safety Systems and Electrical Installations**

E-mail: migalenkok@ukr.net *Department of Emergencies Recovery Lviv State University of Life Safety

Kleparivska str., 35, Lviv, Ukraine, 79007

**Cherkasy Institute of Fire Safety named after Chernobyl Heroes of National University of Civil Defense of Ukraine Onoprienka str., 8, Cherkasy, Ukraine, 18034

\section{Introduction}

Light metals include magnesium, aluminum, titanium, sodium, lithium, and others. Combustion of these metals and their alloys belongs to the fires of class D. By 2014, the fires of class D were divided in fires D1 (combustion of light met-
Copyright $\odot$ 2020, B. Gusar, V. Kovalyshyn, S. Pozdieiev, Vol. Kovalyshyn, O. Zemlianskyi, K. Myhalenko This is an open access article under the CC BY license (http://creativecommons.org/licenses/by/4.0) 
In this research, we consider the class D fires in the presence of magnesium, aluminum, titanium. The course of these fires is practically the same. The use of magnesium and its alloys is practical and effective in the industry. Magnesium is used in the form of metal plates to protect sea vessels and pipelines from corrosion. Magnesium and its alloys are often used in apparatuses of space and aircraft engineering, automotive construction, various units, and responsible devices.

Light metals burn when they are present in the form of products of processing: powders of different dispersion, chips. Class D fires happen in the world every year [1]. The features of light metals, which are combustible, explosive, and flammable, include the ability to explode in the crushed state in the interaction of burning metals with water and some gas fire-extinguishing compounds. Such compounds include refrigerants (chlorofluorohydrocarbon), nitrogen, carbon dioxide (for example, magnesium), etc. The important feature is limited data on analysis that systematizes tactical actions and technical aspects of the use of extinguishing powders when extinguishing the combustion of materials based on magnesium alloy chips.

Let us analyze the most resonant fires of class D, caused by the existence of magnesium alloys [1].

In April 2010, at the factory "Kyivprylad" (Ukraine), which is situated in Harmatna Street, 2, in the Solomensky district of the capital, there was a powerful explosion of magnesium. The explosion was caused by a spark from a gas welding machine, which hit a container with magnesium. As a result of the explosion, two men died. Metal structures of the lift were melted from high temperatures, and the frames in the workshops from the first to the fourth floors collapsed as a result of the explosion.

On February 17, 2016, the explosion of ammunition depots in the Zaporizhya region (Ukraine) led to the fire on the territory of military warehouses. Unknown people dropped ignition items on the territory of the site with the help of unmanned flying vehicles. It was impossible to use water in fire-fighting because it is not effective in extinguishing these metals. There was no primary firefighting equipment, fire extinguishers filled with special powders, and nozzles-extinguishers. The fire tank and soil were used. About 50 places of combustion were detected.

On October 2, 2015, more than 20 firefighters extinguished 47 tons of combusting magnesium at the PolMag plant in the town of Olszowej in the Republic of Poland. At the first stage, there was an unsuccessful attempt to extinguish melted magnesium alloy. The extinguishing powder was used, but the fire was so intense that it was impossible to suppress. There were no necessary devices for feeding fire extinguishing agents [1].

The fire of magnesium in 2010 in Sonneberg inflicted the damage worth millions of euros, 30 tons of magnesium was burned. The localization and elimination of the fire were started late, there was no effective means of primary firefighting.

Aluminum compounds were burning in the fire, which occurred at the "Zenit" plant in Donetsk in 2019. On January 2, 2009, a fire broke out in the shop of cold rolling No. 1, JSC "Zaporizhstal”, where all aluminum was burnt.

The cars with engines made from magnesium-aluminum alloys combusted repeatedly on fires. Water getting on them was the cause of an explosion. Therefore, the extinguishing agent, which showed the greatest efficiency in suppressing such fires, is the use of extinguishing powders of combined action in order to take into consideration the complex nature of fire. In view of this, fire-extinguishing powders require substantial improvement.

Fires of light metals, aluminum, magnesium are extinguished by covering their surface of combustion with a special extinguishing D-powder for isolation of combustible metal, thereby preventing the possibility of fire propagation over the area. There are virtually no class D fires. At first, there may be fires of flammable liquids or solid combustible materials, and then fires of light metals that require combined methods of extinguishing. It is necessary to consider the high temperature of magnesium combustion. Feeding the fire-extinguishing agent under high pressure leads to magnesium and its alloys splatter and increase the combustion area. First, it is necessary to extinguish the light metal, and then other combustible materials of fires of class A, B. Thus, it is necessary to develop a formulation of the fire-extinguishing powder and to improve the technology of extinguishing these fires, taking into consideration the peculiarities of the combustion of magnesium, aluminum, and their alloys. Under such conditions, the successful extinguishing of such fires depends on the thermal isolation capacity of the layer of the fire extinguishing powder under these conditions, as it inhibits any further propagation of a fire. Given the above, it can be noted that for the effective and economical use of the fire-extinguishing powder for suppressing fires of materials based on magnesium alloy chips, it is a relevant problem to determine the amount and intensity of feeding the fire-extinguishing powder to stop the combustion of the fire-extinguishing layer, determined by its thermophysical properties.

\section{Literature review and problem statement}

Magnesium alloys, depending on the content of magnesium in the alloy, a layer of chips, granules, and dust may have combustion temperature from 1,100 to $2,800{ }^{\circ} \mathrm{C}[1,2]$. At this temperature, water is decomposed into hydrogen and oxygen, the combustion takes place with a blast, conventional fire-extinguishing powders burn out. The thickness of the layer, which is applied to the surface of combustible magnesium will depend on the insulating properties of the fire-extinguishing powder for special purposes, Approximate estimation of the required amount of the extinguishing powder for fire-fighting will make it possible to construct fire equipment.

Fires with the combustion of magnesium and other light metals occur annually all over the world. Magnesium and aluminum compounds for ignition of such sites as stadiums, ammunition depots [1] are used increasingly often. Losses are calculated in millions of euros $[1,2]$. Nevertheless, these papers contain limited data on formulations and modes of feeding fire-extinguishing powders, specifically for materials based on magnesium alloy chips as the most likely fires of similar metals to ensure, on the one hand, the high extinguishing effect by deterring a fire by blocking thermal action in the fire cell and, on the other hand, its economic application.

The issue of extinguishing metal fires is considered in the scientific literature from different angles. One part of the papers is aimed at studying the characteristics of the combustion of metals under different conditions, the other focuses on extinguishing and limiting the propagation. However, 
the issue of the influence on these conditions of the thermal properties of the powder layer under conditions of fire was not sufficiently studied.

In paper [3], the combustion of liquid sodium in order to obtain a deeper understanding of the characteristics of both the combustion process and extinguishing by the fire-extinguishing powder were studied. As a result of the study, the authors prove that extinguishing liquid sodium at the initial stage is more effective due to less heating of the lower layers. At the same time, the quantitative interrelation between the technical parameters of the process of powder extinguishing and the parameters of heating the powder layer were not discussed in this paper.

The danger of self-ignition of layers of metal powder mixtures was explored in paper [4]. The article studied the characteristics of the ignition of sediments of metal powders, including zirconium and tantalum mixtures with the purpose of proving the previously proposed two-dimensional model.

The combustion of boron and aluminum mixes was explored in [5]. The authors developed the model for studying the rate of combustion of the boron and aluminum mixture, depending on the dimensions of particles and concentration. The proposed model demonstrated a decrease in the rate of combustion of the mixture and an increase in the required ignition energy at an increase in the mass particle of boron.

The specific features of combustion and selection of fire-extinguishing substances for extinguishing metals were considered in article [6]. The paper notes that such extinguishing agents as water, carbon dioxide, and ordinary extinguishing powder can not be used to suppress the fires of D class. To extinguish a particular kind of metal, it is necessary to use the appropriate dry fire-extinguishing agent. In paper [7], the possibility of using well-known extinguishing agents to stop the burning of various metals was analyzed.

Minimization of the effects of explosions of metal dustair mixtures was studied in paper [8]. It was proved that suppression of deflagration combustion of aluminum dust is possible even in large volumes.

In paper [9], the inhibiting properties of the fire-extinguishing powder of the "ABC" brand during extinguishing aluminum dust were studied. It was shown that inhibiting properties are intensified at the decrease in dimensions of particles of the extinguishing powder. The peculiarity of these works is the limited data that would be concentrated on the combustion of materials based on magnesium alloy chips as one of the most common structural and pyrotechnic materials.

The extinguishing vermiculite-based substance [10], which can be used for extinguishing the fires of several classes, including class D, is known.

As a rule, there are no fires purely of class D. Magnesium or its compounds are the first to combust, followed by solid combustible substances or combustible liquids, that is, the fires of class A take place. Under certain conditions, such fires may be accompanied by explosions. The aspects of protection from explosions at construction sites are discussed in detail in papers [11, 12]. However, the aspects of extinguishing these substances with the powders of combined effects were not studied enough.

Powders KM-1, PCK, substance SUPER D (based on sodium chloride), Ansul Met-L-X Class D, D Favorit M were developed to extinguish the fires of pure class D.
PCK powder is intended for extinguishing combustions of aluminum, magnesium, and other light metals and alloys [13].

Fire extinguishers Amerex Model B570 are refilled with the SUPER D powder and can extinguish the fires containing magnesium alloys, uranium, and powder aluminum [14].

Ansul Met-L-X Class D powder for the fire extinguisher, which extinguishes the fires of lithium, magnesium, sodium, and potassium. In some cases, it will completely extinguish the fires of zirconium, titanium, and sodium-potassium alloy [15].

However, all these powders are not of combined effect and are not used for extinguishing the fires of class A, B. The study of thermophysical properties of these powders makes it possible to significantly increase their fire-extinguishing effect by ensuring the required thermal insulating capacity of the center of a fire of materials based on magnesium alloy chips. At the same time, the development of recommendations for technical parameters of their supply to the fire center makes it possible to increase their economic consumption, thereby improving their tactical characteristics.

\section{The aim and objectives of the study}

The aim of this study is to identify the patterns of the dependence of thermotechnical characteristics of fire-extinguishing powders on the parameters of the insulating layer created by these powders under conditions of extinguishing the powders of magnesium alloys as scientific substantiation of the parameters of powders feeding to prevent fire propagation by thermal insulation of combustion centers.

To achieve the aim, the following tasks were set:

- to carry out experimental measurements of temperature in the center of a

the fire of powders of magnesium alloys and beyond it under the conditions of it being extinguished by the extinguishing powder;

- to create the mathematical model for determining the insulating layer of fire-extinguishing powder and extinguishing intensity on the example of the special purpose powder KM-2 for suppressing fires D, A, B;

- to study the regularities of changes in effective coefficient of thermal conductivity of the insulating layer of fire-extinguishing powder and heat transfer coefficient at the boundary between it and environment, depending on the thickness of the insulating layer;

- to develop the procedure for determining the required amount of the extinguishing powder to achieve the appropriate insulating effect and determine the required thickness of the layer of the extinguishing powder.

\section{Experimental study of the efficiency of extinguishing the combustion of metals}

4. 1. Equipment for the experimental study of temperature in a fire-extinguishing powder layer when extinguishing chips of magnesium alloys

To predict the possibility of thermal insulation of the center of the combustion of chips of magnesium alloys, the experiment under laboratory conditions was carried out, Fig. 1. 


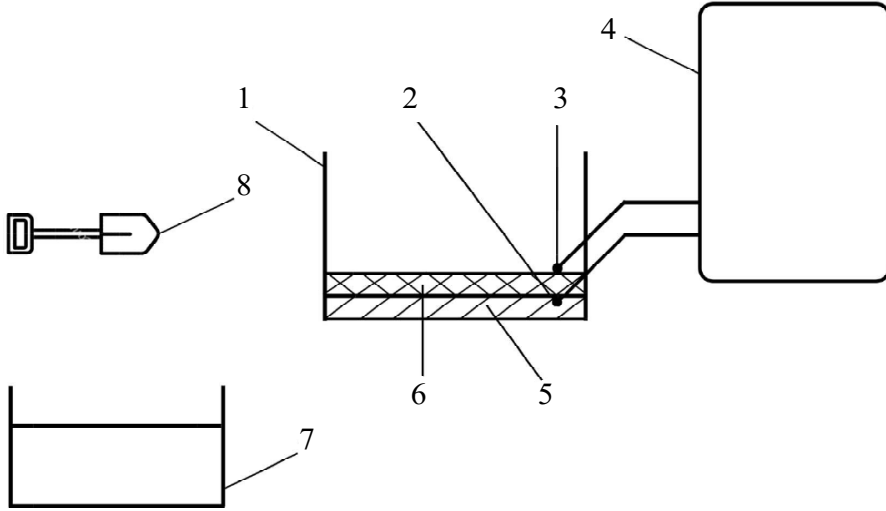

Fig. 1. Schematic of a laboratory plant to determine the efficiency of extinguishing light metals: 1 - heat resistant deco of $15 \times 19 \mathrm{~cm}$; 2 - thermocouple to determine the temperature on the surface of combusting metal; 3 - thermocouple on the powder surface at the boundary with the air; 4 - computer; 5 - chips of magnesium and aluminum alloy; 6 - fire extinguishing powder; 7 - vessel with fireextinguishing powder; 8 - spade to apply powder on a hot surface

4. 2. The procedure of the experimental research into the temperature in a layer of fire-extinguishing powder when extinguishing magnesium alloys chips

The experiment was performed at two stages. At the first stage, there was a study of a thin layer of the extinguishing powder at a lengthy extinguishing process in order to achieve the establishment of the thermal process. In the second stage, several experiments were conducted, for which the establishment of the thermal process was not required [16, 17]. After the experiment, the temperature indicators were obtained. They are shown in Table 1.
1) the thermal process in the layer of the fire-extinguishing powder when extinguishing magnesium alloy chips is not stationary, except for the process in the first experiment, for which such prerequisite is met during the creation of appropriate experimental conditions;

2) the conditions of heat exchange at the boundary between the fire-extinguishing powder and the air remain the same and unchanged for all experiments;

3 ) the temperature of the layer at the boundary with the combustible medium is constant and does not change during the time of extinguishing;

4) the layer of the fire-extinguishing powder is homogeneous, isotropic and contains no cavities;

5 ) accompanying thermal processes in the layer of fire-extinguishing powder are taken into consideration when introducing an effective coefficient of thermal conductivity, determined by empirical indicators;

6 ) effective coefficient of thermal conductivity $\lambda(\delta)$ does not depend on temperature and its value may be dependent on the thickness of the layer of the extinguishing powder $\delta$;

7) specific capacity $C_{p}$ and density $\rho$ of the powder have constant values and do not depend on the temperature or thickness of the layer and are accepted according to the data of papers [2,16, 17].

In view of the adopted basic provisions for the creation of the mathematical model, two types of processes were considered - stationary and non-stationary. The calculation scheme for the stationary process is shown in Fig. 2.

Temperature indicators in the layer of extinguishing powder during the process of extinguishing magnesium alloy chips

\begin{tabular}{|c|c|c|c|c|c|c|}
\hline $\begin{array}{l}\text { No. of } \\
\text { entry }\end{array}$ & $\begin{array}{c}\text { Thickness } \\
\text { of applied } \\
\text { EP, mm }\end{array}$ & $\begin{array}{c}\text { Temperature at the } \\
\text { boundary of metal } \\
\text { and powder, }{ }^{\circ} \mathrm{C}\end{array}$ & $\begin{array}{c}\text { Temperature }(T z) \text { at } \\
\text { the boundary of air } \\
\text { and powder, }{ }^{\circ} \mathrm{C}\end{array}$ & $\begin{array}{l}\text { Time of extin- } \\
\text { guishing, s }\end{array}$ & $\begin{array}{c}\text { Dimen- } \\
\text { sions of } \\
\text { decay }\end{array}$ & $\begin{array}{c}\text { Weight of } \\
\text { consumed } \\
\text { powder }\end{array}$ \\
\hline $1 *$ & 1 & 730 & 170 & 25 & \multirow{6}{*}{$\begin{array}{l}\text { Width } \\
-15 \\
\text { Length } \\
-19\end{array}$} & 26.5 \\
\hline 2 & 3 & 740 & 130 & 20 & & 79.5 \\
\hline 3 & 5 & 735 & 110 & 18 & & 132.5 \\
\hline 4 & 6 & 748 & 94 & 15 & & 159.0 \\
\hline 5 & 8 & 750 & 72 & 12 & & 212 \\
\hline 6 & 10 & 732 & 60 & 10 & & 265 \\
\hline
\end{tabular}

Powder feed intensity, at which temperature $T z$ at the boundary of air - powder would be less than $100{ }^{\circ} \mathrm{C}$, is from 0.372 to $0.93 \mathrm{~kg} / \mathrm{m}^{2} \cdot \mathrm{s}$.

The obtained data can be used to determine the coefficient of thermal conductivity of the layer of fire-extinguishing powder and heat exchange coefficient at the boundary between the air and the powder.

\section{Research results}

5. 1. Basic provisions on creating the mathematical model for studying the thermotechnical properties of the insulating layer of fire-extinguishing powder

To create the mathematical model for the given thermal process, we formulated the following basic provisions:
Table 1

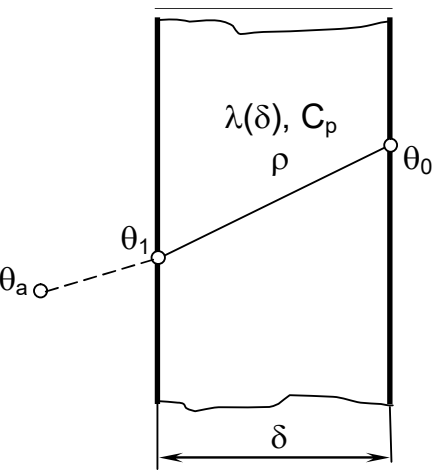

Fig. 2. Calculation scheme for construction of a mathematical model of stationary thermal process in the layer of fire-extinguishing powder during extinguishing magnesium alloy chips

5. 2. Basic mathematical ratios of the mathematical model for studying the thermotechnical properties of the insulating layer of the fire-extinguishing powder

According to the calculation scheme, which is shown in Fig. 2 and given the stationarity of the thermal process for the first experiment according to Table 1, we obtain the equation. This is the equation of thermal balance at the boundary between the air and the layer of the fire-extinguishing powder using Fourier and Newton-Richman laws [18]:

$$
\alpha\left[\theta_{1}-\theta_{a}\right]=\frac{\lambda(\delta)}{\delta}\left[\theta_{0}-\theta_{1}\right],
$$


where $\theta_{0}$ is the temperature of the powder surface on the side of combustion media of the magnesium alloy chips; $\theta_{0}$ is the temperature of the powder surface layer on the side of the boundary between them and the air; $\theta_{0}=20^{\circ} \mathrm{C}$ is the temperature of the air; $\alpha$ is the heat transfer coefficient between the powder layer surface and the air.

For further research, the special coefficient was introduced that establishes the ratio between the thermal conductivity coefficient and heat transfer coefficient, which is determined as:

$$
a_{l}=\frac{\alpha}{\lambda(\delta)}=\frac{\theta_{0}-\theta_{1}}{\delta\left[\theta_{1}-\theta_{a}\right]} .
$$

As an assumption, we accept the provision that such an equation can be written down for all experiments, as the stationary thermal process implies that the temperature gains the highest values. This means that this simplification will lead to determining the approximate temperatures towards an increase in relation to actual.

In the case of the non-stationary thermal process for all experiments, including the first one, before the thermal process enters the established mode, the non-stationary equation of thermal conductivity in the form of $[18,19]$ is used:

$$
\frac{\partial \theta}{\partial t}=\frac{\lambda(\delta)}{C_{p} \rho} \frac{\partial^{2} \theta}{\partial x^{2}} .
$$

Equation (2) is written down taking into consideration the provisions of the calculations formulated above. This equation is solved numerically at the approximation of equation (3) according to the finite difference method. To do this, it is possible to use the calculation scheme, shown in Fig. 3.

According to the scheme shown in Fig. 3, we establish that it is possible to write down boundary conditions of I kind at the boundary between the combustible medium and the layer of fire-extinguishing powder [18, 19]:

$$
\theta||_{x=\delta}=\theta_{0}
$$

For the boundary between the layer of the fire-extinguishing powder and the air, the boundary conditions of the third kind are established [16, 17]:

$$
\left.\lambda(\delta) \frac{\partial \theta}{\partial x}\right|_{x=0}=\alpha\left[\theta_{1}-\theta_{a}\right] .
$$

Using the calculation scheme in Fig. 3, the expression of the finite-differential approximation of the thermal conductivity equation (3) was obtained in accordance with [16, 17], which is shown below:

$$
\theta_{m, k+1}=\theta_{m, k}+\frac{2 \lambda(\delta)}{C_{p} \rho} \frac{\theta_{0, k}-2 \theta_{m, k}+\theta_{1, k}}{\delta^{2}},
$$

In the given equation, parameter $k$ determines the number of the pitch of integration by time, expression (6) is recorded for the magnitude of a pitch by time $\Delta t=1 \mathrm{~s}$.

The expression for the finite-differential approximation of boundary conditions of the third kind at the boundary between the layer of fire-extinguishing powder and the air has the following form $[18,19]$ :

$$
2 \lambda(\delta) \frac{\theta_{m, k}-\theta_{1, k}}{\delta}=a_{l} \lambda(\delta)\left[\theta_{1, m}-\theta_{a}\right]
$$

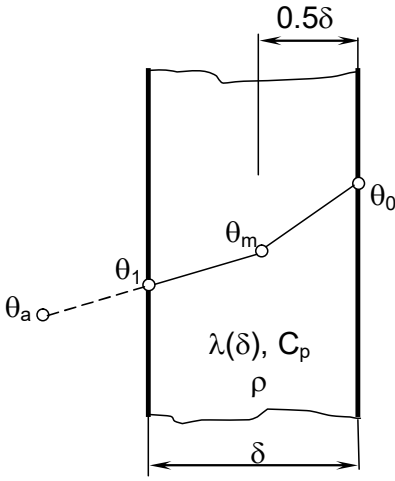

Fig. 3. Calculation scheme for construction of the mathematical model of non-stationary thermal process in the layer of fire-extinguishing powder during extinguishing magnesium alloy chips

In equation (6), the temperature at the boundary between the layer of the fire-extinguishing powder and the air is determined from the expression:

$$
\theta_{1, k}=\frac{2 \lambda(\delta) \theta_{m, k}+a_{l} \delta \lambda(\delta) \theta_{a}}{2 \lambda(\delta)+a_{l} \delta \lambda(\delta)}
$$

Expression (8) is a recurrent formula and can be written down as an equation with respect to variable of magnitude $\lambda(\delta)$ in the form:

$$
\theta_{1, k \max }-\theta_{1 e x p}=0,
$$

where $\theta_{1 \exp }$ is the corresponding value of temperature at the boundary of the layer of the fire-extinguishing powder and the air, according to Table 1.

\section{3. Results of calculating the thermotechnical char-} acteristics of the insulating layer of fire-extinguishing powder

To calculate the heat transfer coefficient, the ratio of the heat transfer coefficient to the thermal conductivity coefficient was determined from formula (2). The determined values of this ratio are given in Table 2 . In addition, in view of papers [16, 17], we accept the corresponding magnitudes of specific thermal capacity and the density of the fire-extinguishing powder, which are also shown in Table 2.

Table 2

The ratio of heat transfer coefficient to thermal conductivity coefficient for experimental situations

\begin{tabular}{|c|c|c|c|c|c|c|}
\hline $\begin{array}{c}\text { Number of experiment } \\
\text { (Table 1) }\end{array}$ & 1 & 2 & 3 & 4 & 5 & 6 \\
\hline $\begin{array}{c}\text { Magnitude of ratio } \\
\alpha / \lambda(\delta), \times 10^{3} \mathrm{~m}\end{array}$ & 3.733 & 1.848 & 1.389 & 1.473 & 1.63 & 1.68 \\
\hline $\begin{array}{c}\text { Specific thermal ca- } \\
\text { pacity, } C_{p}, \mathrm{~J} /\left(\mathrm{kg} \times{ }^{\circ} \mathrm{C}\right)\end{array}$ & \multicolumn{7}{|c|}{1,000} \\
\hline Density, $\rho, \mathrm{kg} / \mathrm{m}^{3}$ & \multicolumn{7}{c|}{950} \\
\hline
\end{tabular}

The first stage of calculation is determining the thermal conductivity coefficient, which according to the calculation provisions and conditions of the experiment is determined by the data of the first experimental situation according to Table 1. Equations (9) and the data from Table 2 are used for this purpose. Equation (9) is solved using the half-division 
method with a preliminary assessment of the numerical value of the solution with the help of the graphic method. Fig. 4 shows the graph of the dependence of the left part of equation (9) on the coefficient of thermal conductivity of the layer of the fire-extinguishing powder with the marked position, where the desired value of the thermal conductivity coefficient for this experimental situation is located.

The predefined value is the first approximation to search for a solution to equation (9) by the algorithm according to the half division method. The heat transfer coefficient is determined after obtaining the value of the thermal conductivity coefficient using formula (2) and by the found value of the ratio of thermal conductivity coefficient to the heat transfer coefficient.

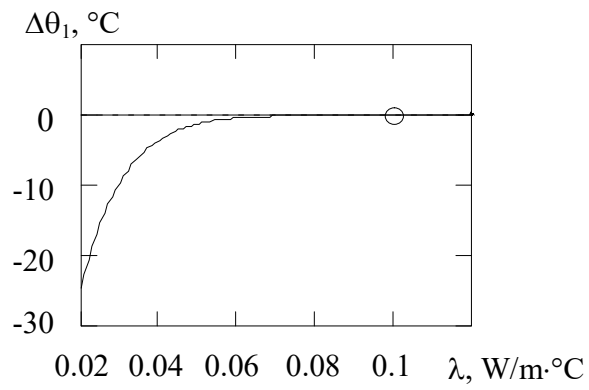

Fig. 4. Dependence of the left part of equation (9) on the coefficient of thermal conductivity of the layer of fireextinguishing powder for the first experimental situation

According to the half-division method and the previous value of the thermal conductivity coefficient, determine the refined value with precision $\sigma=0.001^{\circ} \mathrm{C}$. The obtained refined value of the thermal conductivity coefficient and the value of the heat transfer coefficient are brought to Table 3 .

Table 3

Value of thermal conductivity coefficient and heat transfer coefficient for the first experimental situation

\begin{tabular}{|c|c|}
\hline Number of experiment (Table 1$)$ & 1 \\
\hline Magnitude of ratio $\alpha / \lambda(\delta), \times 10^{3} \mathrm{~m}$ & 3.733 \\
\hline Thermal conductivity coefficient, $\lambda(\delta), \mathrm{W} /\left(\mathrm{m} \times{ }^{\circ} \mathrm{C}\right)$ & 0.106 \\
\hline Heat transfer coefficient, $\alpha, \mathrm{W} /\left(\mathrm{m}^{2} \times{ }^{\circ} \mathrm{C}\right)$ & 395.733 \\
\hline
\end{tabular}

Using the obtained data, we determined thermal conductivity coefficients for other experimental situations with the help of a similar algorithm.

Fig. 5 shows the graphs of dependences of the left part of equation (9) on the coefficient of thermal conductivity of the layer of the fire-extinguishing powder. The positions where there is the desired value, which will be used as a preliminary approximation for the half-division method, are marked on them.

We determine the refined value with precision $\sigma=0.001{ }^{\circ} \mathrm{C}$ using the half- division method and preliminary values of the thermal conductivity coefficient. The resulting refined values of thermal conductivity coefficients are brought down to Table 4.

The resulting values of the thermal conductivity coefficient enable the establishment of its dependence on the thickness of the fire-extinguishing powder layer, presented in the form of the appropriate chart in Fig. 6.

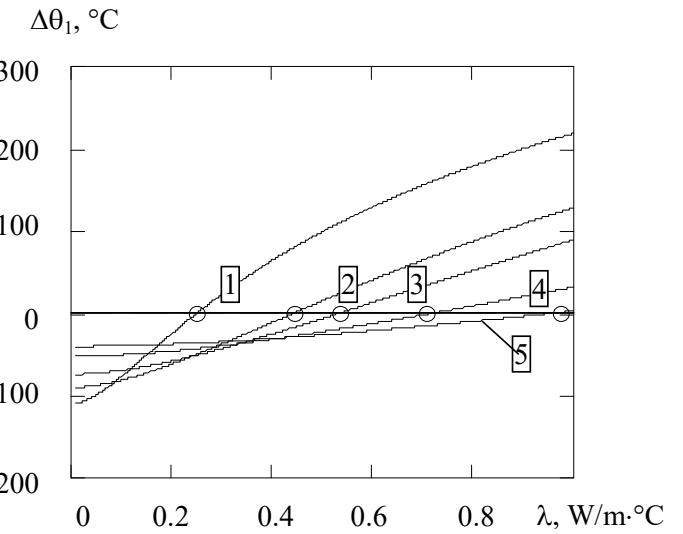

Fig. 5. Dependence of the left part of equation (9) on the coefficient of thermal conductivity of the layer of fireextinguishing powder for different experimental situations:

1 - situation $2 ; 2$ - situation $3 ; 3$ - situation 4 ; $4-$ situation $5 ; 5-$ situation 6

Table 4

Value of thermal conductivity coefficients for various experimental situations

\begin{tabular}{|c|c|c|c|c|c|}
\hline $\begin{array}{c}\text { Number of experiment } \\
\text { (Table 1) }\end{array}$ & 2 & 3 & 4 & 5 & 6 \\
\hline $\begin{array}{c}\text { Thermal conductivity coef- } \\
\text { ficient } \lambda(\delta), \mathrm{W} / \mathrm{m} \times{ }^{\circ} \mathrm{C}\end{array}$ & 0.250 & 0.442 & 0.532 & 0.717 & 0.953 \\
\hline $\begin{array}{c}\text { Thickness of powder layer, } \\
\delta, \mathrm{mm}\end{array}$ & 3 & 5 & 6 & 8 & 10 \\
\hline $\begin{array}{c}\text { Heat transfer coefficient, } \alpha, \\
\mathrm{W} /\left(\mathrm{m}^{2} \times^{\circ} \mathrm{C}\right)\end{array}$ & \multicolumn{5}{|c|}{395.733} \\
\hline
\end{tabular}

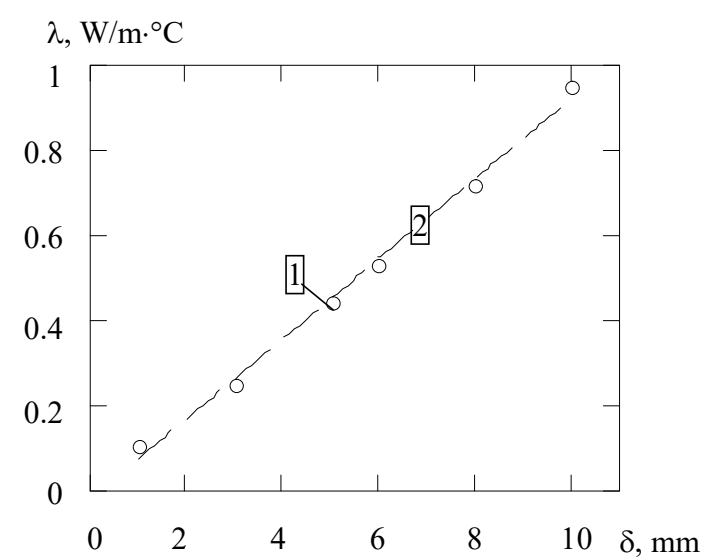

Fig. 6. Charts of the dependence of the coefficient of thermal conductivity of the layer of fire-extinguishing powder on its

thickness: 1 - obtained in the conducted experiment; 2 - linear regression

The charts in Fig. 6 show that the dependence of the coefficient of thermal conductivity of the layer of the fire-extinguishing powder on its thickness is close to linear. Regression analysis conducted by the algorithm given in paper [20] made it possible to determine corresponding coefficients. The expression of the obtained linear regression is shown below.

$$
\lambda(\delta)=-0.016+93.907 \times \delta,
$$

where $\delta$ is the thickness of the layer of the fire-extinguishing powder in meters. 
The resulting regressive dependence makes it possible to determine the necessary layer of the fire-extinguishing powder to provide its desired heat insulating ability.

To predict the possibilities of thermal insulation of the center of the combustion of chips of magnesium alloys, it is possible to use the algorithm developed by us based on the solution of equation (9). In this case, formula (10) should be used to determine the thermal conductivity coefficient. The calculation source data are given in Table 5 .

Table 5

Source data for determining the thickness of the fireextinguishing powder layer to ensure the necessary thermal insulation

\begin{tabular}{|c|c|}
\hline Heat transfer coefficient, $\alpha, \mathrm{W} /\left(\mathrm{m}^{2} \times{ }^{\circ} \mathrm{C}\right)$ & 395.733 \\
\hline $\begin{array}{c}\text { Temperature at the boundary with combustible } \\
\text { medium, } \theta_{0},{ }^{\circ} \mathrm{C}\end{array}$ & 900 \\
\hline Required temperature at the boundary with the air, $\theta_{b},{ }^{\circ} \mathrm{C}$ & 80 \\
\hline Time of extinguishing, $t, \mathrm{~s}$ & 60 \\
\hline
\end{tabular}

Having carried out the necessary calculations using formulas (6) to (9), the value of the required thickness of the fire-extinguishing powder layer was found $\delta=45.2 \mathrm{~mm}$.

\section{Discussion of results of studying the thermal insulation of the fire center by the layer of fire-extinguishing powder}

Analyzing the experimental data, it is possible to notice that the dependence of temperature on the non-heated side of the heat-insulating layer of the fire-extinguishing powder on its thickness looks close to linear. Given that the insulating layer is relatively thin, we can assume that heat exchange conditions at the boundaries of this layer do not change substantially. This, in turn, proves the correctness of the assumption that the heat exchange coefficient is constant.

The value of the heat exchange coefficient $\alpha=$ $=395.733 \mathrm{~W} /\left(\mathrm{m}^{2} \times{ }^{\circ} \mathrm{C}\right)$, determined for the first experimental situation, correlates with the data known from literary sources, for example, paper [21].

An important result is the dependence of effective thermal conductivity coefficient on the thickness of the insulating layer of the powder, which is close to linear. This dependence makes it possible to predict the thermal insulation ability of the powder layer and determine its minimum thickness, at which the greatest effect is achieved. The linearity of the dependence of effective thermal conductivity coefficient correlates with the experimental dependence, shown in Table 1, which proves the correctness of the accepted hypothesis. The obtained approximating linear dependence (10) made it possible to determine such thickness in the assumption that the maximum temperature of the non-heated surface of the fire-extinguishing powder layer should not exceed $120{ }^{\circ} \mathrm{C}$, - it is equal to $\delta=45.2 \mathrm{~mm}$.

The obtained results in totality make it possible to use the appropriate powder feed to solve the problem of heat isolation of centers of the fire of magnesium alloys chips by establishing the necessary thickness of the powder layer, which performs a thermal insulating function to prevent fire propagation at storage facilities of such materials.
This calculation method involves the performance of the following procedures:

1) the initial minimum magnitude of the thickness of the insulating fire-extinguishing powder layer is accepted based on the practical recommendations for its feeding to the fire cell during its extinguishing;

2) based on equations (6) to (10) and the data from Table 5, the temperature from the non-heated side of the insulating layer of the fire-extinguishing powder is calculated;

3 ) the resulting temperature is compared with the permissible value of the temperature on the non-heated side;

4) if the temperature on the non-heated side exceeds the permissible value, the calculation is repeated, if not, the calculation is terminated, and the current layer thickness is accepted as the one recommended to achieve the desired heat-insulating effect.

The obtained value of the thickness of the insulating layer of the fire-extinguishing powder $\delta=45.2 \mathrm{~mm}$ shows that this method is effective.

All the data were obtained as a result of the conducted experiments for the fire-extinguishing powder, which is made based on phosphate-ammonium salts. Accordingly, the obtained data on the thermophysical characteristics are limited to the class of such powders, but if necessary, the same analysis can be performed for other types of powders, which is a direction of further research.

\section{Conclusions}

1. The experimental temperature measurements were carried out in the center of the fire of magnesium alloys powders and outside it on conditions of its suppression by the fire-extinguishing powder. As a result, we obtained temperature indicators of heating of the heated side of the insulation layer of the fire-extinguishing powder, which averaged $740{ }^{\circ} \mathrm{C}$, and those of the non-heated side that did not exceed $170{ }^{\circ} \mathrm{C}$.

2. The mathematical model for determining the temperature on the non-heated side of the insulating layer of the fire-extinguishing powder and extinguishing intensity on the example of special-purpose powder KM-2 for suppressing fires D, A, B was created.

3. Based on the created model, the coefficient of heat transfer between the non-heated side of the isolating layer of the fire-extinguishing powder and the environment was determined, it is $\alpha=395.733 \mathrm{~W} /\left(\mathrm{m}^{2} \times{ }^{\circ} \mathrm{C}\right)$. The dependence of effective thermal conductivity on the thickness of the layer was explored. It was shown that this dependence is close to linear and can be described by formula $\lambda(\delta)=-0.016+93.907 \times \delta$.

4 . We developed the procedure for determining the required amount of the fire-extinguishing powder, the specific feature of which is that it determines the required thickness of the heat-insulating powder layer, which makes it possible to achieve the necessary heat-insulating effect and simultaneously avoid unreasonable consumption of the costly fire-extinguishing powder. This thickness of the heat-insulating layer of the extinguishing powder is achieved by the appropriate parameters of its feeding to the fire center. Based on this procedure, the necessary thickness of the layer of the studied fire-extinguishing powder, which was $\delta=45.2 \mathrm{~mm}$, was determined. 


\section{References}

1. Kovalyshyn, V., Marych, V., Novitskyi, Y., Gusar, B., Chernetskiy, V., Mirus, O.-Z. (2018). Improvement of a discharge nozzle damping attachment to suppress fires of class D. Eastern-European Journal of Enterprise Technologies, 5 (5 (95)), 68-76. doi: https://doi.org/10.15587/1729-4061.2018.144874

2. Antonov, A., Stylyk, I. (2013). Test methods for dry chemical powders for the determination of their fire extinguishing capability for D - class of fire. Naukovyi visnyk UkrNDIPB, 2 (28), 242-248. Available at: http://nbuv.gov.ua/UJRN/Nvundipb_2013_2_40

3. Huo, Y., Zhang, Z.-G., Zou, G.-W. (2020). Experimental study on the thermal flow characteristics of a columnar sodium fire affected by a small amount of fire extinguishing powder in a cylindrical confined space. Applied Thermal Engineering, 170, 114983. doi: https://doi.org/10.1016/j.applthermaleng.2020.114983

4. Dufaud, O., Bideau, D., Le Guyadec, F., Corriou, J.-P., Perrin, L., Caleyron, A. (2014). Self ignition of layers of metal powder mixtures. Powder Technology, 254, 160-169. doi: https://doi.org/10.1016/j.powtec.2013.11.053

5. Afzalabadi, A., Poorfar, A. K., Bidabadi, M., Moghadasi, H., Hochgreb, S., Rahbari, A., Dubois, C. (2017). Study on hybrid combustion of aero-suspensions of boron-aluminum powders in a quiescent reaction medium. Journal of Loss Prevention in the Process Industries, 49, 645-651. doi: https://doi.org/10.1016/j.jlp.2017.08.012

6. Sharma, T. P., Varshney, B. S., Kumar, S. (1993). Studies on the burning behaviour of metal powder fires and their extinguishment: Part II - Magnesium powder heaps on insulated and conducting material beds. Fire Safety Journal, 21 (2), 153-176. doi: https:// doi.org/10.1016/0379-7112(93)90040-w

7. Nam, K.-H., Lee, J.-S. (2018). Study on the effective response method to reduce combustible metal fire. Journal of the Korea Academia-Industrial cooperation Society, 19 (12), 600-606. doi: https://doi.org/10.5762/KAIS.2018.19.12.600

8. Taveau, J., Vingerhoets, J., Snoeys, J., Going, J., Farrell, T. (2015). Suppression of metal dust deflagrations. Journal of Loss Prevention in the Process Industries, 36, 244-251. doi: https://doi.org/10.1016/j.jlp.2015.02.011

9. Jiang, H., Bi, M., Li, B., Zhang, D., Gao, W. (2019). Inhibition evaluation of ABC powder in aluminum dust explosion. Journal of Hazardous Materials, 361, 273-282. doi: https://doi.org/10.1016/j.jhazmat.2018.07.045

10. Hagge, H., Simpson, T., Chattaway, A. (2018). Vermiculite based fire suppression agent. No. 15/935,620. declareted: 26.03.2018; published: 26.08.2019. Available at: https://patents.google.com/patent/US20190290950A1/en

11. Zemlianskiy, O., Maladyka, I., Miroshnik, O., Shkarabura, I., Kaplenko, G. (2017). Forecasting the emergency explosive environment with the use of fuzzy data. Eastern-European Journal of Enterprise Technologies, 6 (4 (90)), 19-27. doi: https:// doi.org/10.15587/1729-4061.2017.116839

12. Pozdieiev, S., Myhalenko, K., Nuianzin, V., Zemlianskyi, O., Kostenko, T. (2020). Revealing patterns of the effective mechanical characteristics of cellular sheet polycarbonate for explosion venting panels. Eastern-European Journal of Enterprise Technologies, 1 (1 (103)), 32-39. doi: https://doi.org/10.15587/1729-4061.2020.192680

13. Ognetushitel' poroshkoviy spetsial'niy OPS-5 Diapazon+. Available at: https://www.magazin01.ru/catalog/ognetushiteli/Specialnye-ognetushiteli-klass-D/Ognetushitel-poroshkovyy-specialnyy-OPS-5-z-D-U2/

14. Class D Stored Pressure Dry Powder Extinguisher. Available at: https://www.amerex-fire.com/products/class-d-stored-pressuredry-powder-extinguisher/

15. Ansul Met-L-X Class D Extinguisher Powder, 50 lb pail. Available at: https://www.ansul.com/en/us/DocMedia/F-76230.pdf

16. Kovalyshyn, V., Marych, V., Gusar, B., Navalianyi, V., Fedyuk, Y. (2019). Jusitfication of dry chemical powders testing procedure. Fire Safety, 33, 53-59. doi: https://doi.org/10.32447/20786662.33.2018.07

17. Husar, B., Kovalyshyn, V., Marych, V., Lozynskyi, R., Pastukhov, P. (2020). Combined extinguishing of class D, class A and class B fires. Fire Safety, 35, 30-34. doi: https://doi.org/10.32447/20786662.35.2019.05

18. Isachenko, V. P. et. al. (1981). Teploperedacha. Moscow: «Energoizdat», 415.

19. Matsevitiy, Yu. M. (2002). Obratnye zadachi teploprovodnosti. Vol. 1: Metodologiya. Kyiv: Naukova dumka, 408.

20. Beshelev, S. D., Gurvich, F. G. (1980). Matematiko-statisticheskie metody ekspertnyh otsenok. Moscow: Statistika, 263.

21. Drayzdeyl, D.; Koshmarov, Yu. A., Makarov, V. E. (Eds.) (1990). Vvedenie v dinamiku pozharov. Moscow: Stroyizdat, 424. 